\title{
Arterial Thrombus in a Protein C Deficient Patient
}

\author{
Eyad Mansour $^{1}$, Alena Isaeva ${ }^{1}$ \\ 1. Cardiology, Lebanese Geitaoui Hospital, Beirut, LBN
}

Corresponding author: Eyad Mansour, eyadmansour97@gmail.com

\begin{abstract}
Protein C is a Vitamin K derivative that plays an essential role in anticoagulation. Protein C deactivates clotting factors Va and VIIIa; therefore, a deficiency in this protein leads to over expression and activation of these factors and essentially a hypercoagulable, prothrombotic state. Although studies have shown that the cardinal manifestation of protein $\mathrm{C}$ deficiency is venous thromboembolism, we present a case of a patient in his third decade with a myocardial infarction on a background of protein C deficiency and minimal cardiovascular risk factors. Similar cases of patients presenting with arterial thrombus on background of protein C deficiency have been reported; therefore, it is imperative to acknowledge protein C deficiency as a possible cause of acute, premature myocardial infarctions in young patients with minimal or no risk for cardiovascular disease.
\end{abstract}

Categories: Cardiology, Emergency Medicine, Hematology

Keywords: protein c deficiency, arterial thrombus, acute myocardial infarction

\section{Introduction}

Protein C, also known as coagulation factor XIV [1] is a Vitamin K dependent zymogen. The inactive zymogen circulates in the blood at a concentration of $4 \mu \mathrm{g} / \mathrm{mL}$ and is catalyzed into its active serineprotease enzyme activated protein $\mathrm{C}$ form by thrombin when bound to endothelial glycoprotein thrombomodulin [2-3]. The activated form of Vitamin C plays a crucial role in regulating anticoagulation, inflammation, preserving permeability of blood vessels, and cell death. Its anticoagulation function is achieved through the inactivation of clotting factors Va and VIIIa which are essential for factor X activation and the generation of thrombin [4]. Consequently, a deficiency in protein C induces hypercoagulability and thrombophilia. The most common manifestation of a protein C deficiency is venous thromboembolism; however, there has been several reports of arterial disease and myocardial infarctions occurring in young adults with congenital protein $\mathrm{C}$ deficiency but no significant cardiovascular risk factors [5]. An association between protein $\mathrm{C}$ deficiency and arterial thrombosis is controversial and a correlation between the two has not yet been made. Here we report a case of a 32-year-old patient who presented with a myocardial infarction secondary to a protein $\mathrm{C}$ deficiency and some minor cardiovascular risk factors.

Received 11/04/2019

Review began 11/06/2019 Review ended 11/10/2019 Published 11/12/2019

\section{() Copyright 2019}

Mansour et al. This is an open access article distributed under the terms of the Creative Commons Attribution License CC-BY 3.0., which permits unrestricted use, distribution, and reproduction in any medium, provided the original author and source are credited.

\section{Case Presentation}

A 32-year-old Middle Eastern male was admitted to the hospital following a 2-h episode of severe retrosternal chest pain that radiated to his left shoulder. Shortness of breath, diaphoresis, and nausea accompanied the chest pain. His medical history was significant for alcohol and tobacco use (two pack years), and a negative family history of cardiovascular disease. The patient has no other major cardiovascular risk factors. The patient denied any abuse of cocaine or illicit drugs. Physical examination was unremarkable and hemodynamics was stable at admission. Immediately after his arrival the patient was admitted to the ED where electrocardiography showed ST elevations maximal in V1-V4 and ST depression in leads II, III, and arteriovenous fistula (AVF) (Figure 1). Troponin T concentration was $1.10 \mathrm{ng} / \mathrm{mL}$ (normal 0.0-0.10 ng/mL) and creatine kinase peaked at $14375 \mathrm{U} / \mathrm{L}$. Coronary angiography was then preformed and revealed total occlusion of the left anterior descending artery (LAD) (Figure 2). The remaining coronary arteries were normal. Percutaneous coronary intervention was preformed and a stent was placed as part of the immediate management of anterior wall infarction. Coagulation profile was then assessed and a diagnosis of protein $\mathrm{C}$ deficiency was made (Table 1). Following admission and adequate management, the patient's chest pain resolved although serial cardiac enzyme concentrations were still elevated. An echocardiogram prior to the patient's discharge showed a slightly decreased ejection fraction with retrosternal hypokinesis. The patient was then discharged on warfarin, aspirin, metoprolol, and a loop diuretic. 


\section{Cureus}

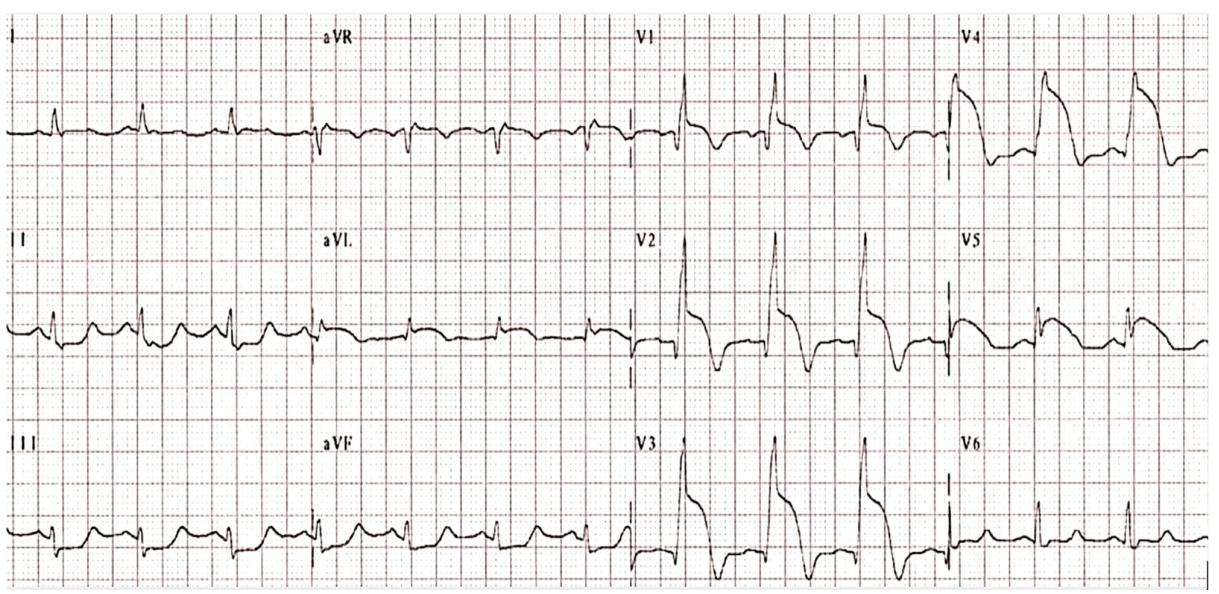

FIGURE 1: Electrocardiograph showing anteroseptal ST elevation.

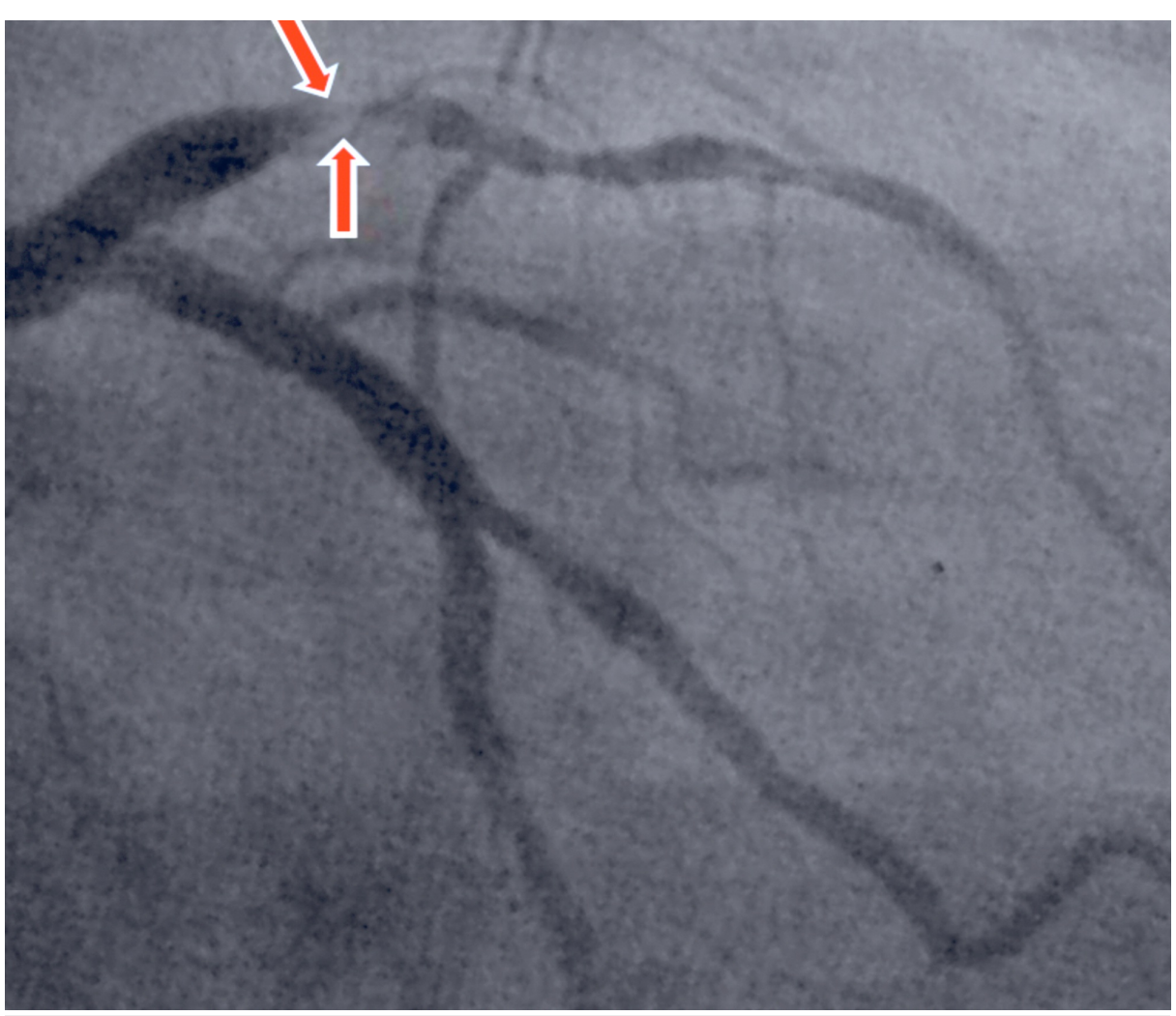

FIGURE 2: Angiogram revealed total thrombotic occlusion of the left anterior descending artery. 


\section{Cureus}

\begin{tabular}{|c|c|c|}
\hline Test & Patient's value & Normal range \\
\hline Protein C & $46 \%$ & $70 \%-140 \%$ \\
\hline Protein S & $90 \%$ & $70 \%-123 \%$ \\
\hline Antithrombin III & $83 \%$ & $80 \%-120 \%$ \\
\hline International normalized ratio (INR) & 1.07 & 1 \\
\hline Prothrombin time (PT) & $12.1 \mathrm{~s}$ & $11-15 \mathrm{~s}$ \\
\hline Activated partial thromboplastin time (APPT) & $14.6 \mathrm{~s}$ & $26-36 \mathrm{~s}$ \\
\hline Factor 5 Leiden mutation & Not detected & - \\
\hline
\end{tabular}

TABLE 1: Hypercoagulable panel examination.

\section{Discussion}

Protein $\mathrm{C}$ deficiency can either be inherited or acquired, the former being passed on in an autosomal dominant fashion and its gene located on chromosome 2q13-q14. The prevalence of heterozygous protein C is 1 in 300 [6-7] and is labeled as such when protein $C$ levels are $<60 \%$. A protein $C$ deficiency homozygous individual has no detectable levels of protein $\mathrm{C}$ and unlike heterozygotes, which comes to clinical attention in the third decade of life, the homozygous state usually targets neonates as 'purpura fulminans neonatalis.' Protein C deficiency or resistance against its activated complex results in excess clothing factors IXa and Xa activity and hypercoagulability $[6,8]$. Protein $\mathrm{C}$ deficiency usually leads to mainly venous disease rather than arterial with the predominant clinical symptom being recurrent venous thrombus [6]. Although the likelihood of venous disease is seven-fold that of arterial disease [9], some cases of myocardial infarctions and strokes have been reported. A study conducted in heterozygous protein $\mathrm{C}$ deficient patients showed prevalence of arterial disease in only $7.1 \%$ of the patients [10]. Although the number of patients who suffer from arterial thrombus on a background of protein $\mathrm{C}$ deficiency is low and there is not enough literature to prove the correlation between the two, it is essential to not undermine this relation.

Management of protein $\mathrm{C}$ deficiency revolves around preventing thrombus formation. Lifestyle changes is an imperative part of the management and includes but is not limited to: smoking cessation, dietary changes, exercise, discontinuing estrogen supplements and contraceptives that include estrogen, and avoiding prolonged immobility [11]. The majority of protein C deficient patients do not develop thrombi and thus treatment is not required [12-13]. However, patients who are at increased risk of thrombus formation, like in the event of a surgery or pregnancy, a family history of abnormal blood clotting [14], or with previous abnormal clotting episodes are usually treated with anticoagulants such as heparin and warfarin, which lower the chance of thrombus formation in the future [12].

In 2007 the Food and Drug Administration (FDA) approved a synthetic protein C concentrate as a supplement in deficient patients. Studies have shown that high intravenous doses of synthetic protein $\mathrm{C}$ can help thin blood and prevent clot formation [15]. Protein C concentrate can also be used prophylactically during surgery, pregnancy delivery, or in the presence of an overwhelming blood stream infection (sepsis) [13]. As there are no guidelines as to who is to be given protein $\mathrm{C}$ concentrate, it is currently only being administered in high risk patients or when heparin alone cannot be safely administered due to the increased risk of bleeding [13]. However, in cases of severe protein C deficiency, protein C concentrate has been dispensed for regular use [13].

Patients with protein $\mathrm{C}$ deficiency are strongly advised to inform nurses and physicians about their deficiency prior to any procedure or surgery. Individuals with a family history of protein C deficiency or hereditary thrombophilia are recommended to undergo a screening process for early detection.

\section{Conclusions}

It is imperative to acknowledge protein C deficiency as a cause of acute premature myocardial infarctions in young patients with minimal or no risk factors for cardiovascular disease as effective therapy can prevent potentially fatal consequences. Detected patients should be advised to comply with their medication and should be made aware of the possible complications of their condition. The mentioned patient will be treated with long-term warfarin, aspirin, metoprolol, loop diuretic, and lifestyle changes.

\section{Additional Information}

\section{Disclosures}


Human subjects: Consent was obtained by all participants in this study. Conflicts of interest: In compliance with the ICMJE uniform disclosure form, all authors declare the following: Payment/services info: All authors have declared that no financial support was received from any organization for the submitted work. Financial relationships: All authors have declared that they have no financial relationships at present or within the previous three years with any organizations that might have an interest in the submitted work. Other relationships: All authors have declared that there are no other relationships or activities that could appear to have influenced the submitted work.

\section{References}

1. Contemporary diagnosis and management of patients with myocardial infarction in the absence of obstructive coronary artery disease: a scientific statement from the American Heart Association. (2019). Accessed: 7 June 2019: https://www.ahajournals.org/doi/abs/10.1161/CIR.0000000000000670.

2. Dahlback B: Advances in understanding pathogenic mechanisms of thrombophilic disorders . Blood. 2008, 112:19-27.

3. Clouse L, Comp P: The regulation of hemostasis: the protein C system . N Engl J Med. 1986, 314:1298-1304.

4. Walker F: Regulation of bovine activated protein $\mathrm{C}$ by protein $\mathrm{S}$ : the role of the cofactor protein in species specificity. Thromb Res. 1981, 22:321-327.

5. Coller B, Owen J, Jesty J, et al.: Deficiency of plasma protein S, protein C, or antithrombin III and arterial thrombosis. Arteriosclerosis. 1987, 7:456-462.

6. Eshtehardi P, Ghassemi-Kakroodi P, Garachemani A, Eslami M, Moayed D: Coronary thrombosis and myocardial infarction as the initial manifestation of protein $\mathrm{C}$ deficiency in a 20 -year-old man. Heart Lung. 2011, 40:112-114.

7. Hayashi K, Sone T, Kondoh J, et al.: Prevalence of activated protein C resistance in acute myocardial infarction in Japan. Jpn Heart J. 1997, 38:769-778.

8. Kario K, Matsuo T, Tai S, Sakamoto S, Yamada T, Miki T, Matsuo M: Congenital protein c deficiency and myocardial infarction: concomitant factor VII hyperactivity may play a role in the onset of arterial thrombosis. Thromb Res. 1992, 67:95-103.

9. Naghavi M: Global, regional, and national burden of suicide mortality 1990 to 2016: systematic analysis for the Global Burden of Disease Study. BMJ. 2016, 2019:194.

10. De Stefano V, Leone G: Arterial thrombosis as clinical manifestation of congenital protein C deficiency . Ann Hematol. 1991, 62:180-183.

11. Sabine Kroiss M: Use of human protein $\mathrm{C}$ concentrates in the treatment of patients with severe congenital protein C deficiency. Biologics. 2010, 4:51-60.

12. Congenital protein C or S deficiency. (2019). Accessed: 11 June 2019: http://www.nlm.nih.gov/medlineplus/ency/article/000559.htm.

13. Protein C deficiency. (2019). Accessed: 11 June 2019: http://patientblog.clotconnect.org/2011/06/15/protein-c-deficiency/.

14. Craig R: Skyscape and Medscape. J Med Libr Assoc. 2016, 104:185-186.

15. Human medicines European public assessment report (EPAR): ceprotin, human protein C, purpura fulminans, protein C deficiency, Date of authorisation: 15/07/2001, Revision: 12, Status: Authorised. Case Med Res. 2018, 